\title{
Embryo Collection from Miniature Pigs and Production of the Piglets after Transfer to Common Pig Recipients
}

\author{
Hirohito YAMAKAWA, Hiroshi NAGASHIMA, \\ Yukio KATO, and Yoshikuni TANIOKA* \\ Feed Research Station, Nisshin Flour Milling Co., Ltd., 1242-6 \\ Iguchi, Nishinasuno-machi, Nasu-gun, Tochigi 329-27 and \\ *Central Institute for Experimental Animals, 1430 Nogawa, \\ Miyamae-ku, Kawasaki-shi, Kanagawa 213, Japan
}

(Received 22 November 1989/Accepted 2 March 1990)

Embryo collection from Göttingen miniature pigs and transfer to common pig recipients were performed. Embryos were collected 2 to 6 days after the onset of estrus. Two to 7 eggs including unfertilized ova were collected from a naturally ovulated donor and more eggs ( 7 to 15) were obtained from a superovulated donor. A total of 21 piglets were born after transfer of 33 miniature pig embryos to two common pig recipients. Among them 12 were stillbirths which seemed to have resulted from suffocation during the parturition. Such an embryo transfer technique will be utilized as an inventive method for the purposes such as international exchange of the particular strains of miniature pigs, establishment of a SPF miniature pig herd and so on.

\section{ミニブタからの初期胚採取および家畜ブタへの \\ 移植によるミニブタの生産 \\ 山川宏人 · 長嶋比呂志 - 加藤行男 - 谷岡功邦* \\ 日清製粉(侏)那須研究所 \\ *財団法人実験動物中央研究所}

ブタは, 一般に心臓血管系, 消化器系, 免疫系, 皮庙 組織などがヒトのそれと類似しており，動脈硬化症など の循環器系疾患, 胃潰瘍などの消化器系疾患, 免度グ口 ブリンに関する研究や, 皮庙科領域の研究に大変有用な 動物であるとされている $[4 ， 5]$ 。しかしながら，家音 のブタは，体格が大きく取扱いが困難であるため，実験 用として各種の小型のブタが開発されてきた。近年, その扱い易さと，前述のごとくヒトとの類似性が高い ところから, 医学, 薬学分野での, ミニチニアピッグ (miniature pig), 通称ミニブタの使用が增加の傾向に ある $[3,4,5]$ 。

我々は, このミニブタの繁殖を効率良く行ら上で, 肧
移植技術が極めて有効な手段になると考兄、ミニブタの 中です最す小さく, 日本で最も多く使われている，ゲッ チンゲン (Göttingen) 系のミニブタから初期肧を採取 し, 家畜ブタへの移植によるミニブタの生産を行ったの で，その概要を報告する。

肧の採取: 肧のドナーとして, 生後10〜12 ヶ月, 体重 $30 \sim 40 \mathrm{~kg}$ のゲッチンゲン系ミニブタ倠を用いた。一部 のドナーに対しては, PMS 500単位, hCG 500単位の筋 肉内注射による多排卵処置を施した。ドナーは, 発情期 間中毎日 1 回, 約24時間間隔で繁殖能力の確認されてい る同系の雄ブタと交配させた。泼の採取は, 雄許容開始 日をday-0 として, day-2〜6に行った。塩酸ケタミ 
Table 1. Result of embryo collection from Göttingen miniature pigs

\begin{tabular}{|c|c|c|c|c|c|c|c|c|c|c|c|}
\hline \multirow[b]{2}{*}{$\begin{array}{c}\text { Donor } \\
\text { No. }\end{array}$} & \multirow[b]{2}{*}{$\begin{array}{l}\text { Super- } \\
\text { ovulation }\end{array}$} & \multirow{2}{*}{$\begin{array}{c}\text { Duration } \\
\text { of estrus } \\
\text { (days) }\end{array}$} & \multirow{2}{*}{$\begin{array}{l}\text { Embryo } \\
\text { collection } \\
\text { (day-) }^{*}\end{array}$} & \multirow{2}{*}{$\begin{array}{l}\text { No. of } \\
\text { embryos } \\
\text { collected }\end{array}$} & \multicolumn{7}{|c|}{ Stages of collected embryos ${ }^{* *}$} \\
\hline & & & & & $\begin{array}{l}2-4 \\
\text { cell }\end{array}$ & $\begin{array}{l}5-8 \\
\text { cell }\end{array}$ & M & B & EXB & $\mathrm{HB}$ & $\mathrm{U}$ \\
\hline 6 & - & 3 & 2 & 7 & 7 & - & - & - & - & - & - \\
\hline 2 & - & 3 & 4 & 6 & - & 4 & 1 & - & - & - & 1 \\
\hline 34 & - & 4 & 5 & 4 & 4 & - & - & - & - & - & - \\
\hline 6 & + & 2 & 5 & 10 & - & - & 7 & 2 & - & - & 1 \\
\hline 2 & + & 4 & 5 & 15 & 1 & 12 & - & - & - & - & 2 \\
\hline 7 & - & 3 & 6 & 6 & - & - & 1 & 5 & - & - & - \\
\hline 7 & - & 2 & 6 & 2 & - & - & - & - & 1 & 1 & - \\
\hline 3 & - & 3 & 6 & 6 & - & - & 4 & 2 & - & - & - \\
\hline 3 & + & 3 & 6 & 7 & - & - & 3 & 4 & - & - & - \\
\hline $\begin{array}{l}*: \\
\text { expa }\end{array}$ & $\begin{array}{l}\text { est of estr } \\
\text { led blastoc }\end{array}$ & $\begin{array}{l}=\text { day }-O \\
\text { sts } \quad \text { HB }\end{array}$ & $\begin{array}{l}* * \mathrm{M}: \\
\text { latched bla }\end{array}$ & $\begin{array}{l}\text { orulae } \\
\text { cysts }\end{array}$ & $\begin{array}{l}\text { : bla } \\
\text { : unf }\end{array}$ & $\begin{array}{l}\text { tocys } \\
\text { ertiliz }\end{array}$ & $\begin{array}{l}\text { sts } \\
\text { zed }\end{array}$ & & XX : & & \\
\hline
\end{tabular}

Table 2. Transfer of Göttingen miniature pig embryos to common pig recipients

\begin{tabular}{|c|c|c|c|c|c|c|}
\hline $\begin{array}{c}\text { Recipient } \\
\text { No. }\end{array}$ & $\begin{array}{c}\text { No. of } \\
\text { corpora } \\
\text { lutea }\end{array}$ & $\begin{array}{c}\text { No. of } \\
\text { embryos } \\
\text { transferred }\end{array}$ & $\begin{array}{c}\text { Stages } \\
\text { and no. of } \\
\text { embryos } \\
\text { transferred }\end{array}$ & $\begin{array}{l}\text { Gestation } \\
\text { length } \\
\text { (days) }\end{array}$ & $\begin{array}{c}\text { No. of } \\
\text { piglets } \\
\text { (Stillbirths) }\end{array}$ & $\begin{array}{c}\text { Developmental } \\
\text { rate of } \\
\text { transferred } \\
\text { embryos }(\%)\end{array}$ \\
\hline & & & $5-8$ cell : 12 & & 9 & \\
\hline 39 & 16 & $19^{*}$ & $\mathrm{M}: 3$ & 112 & (7) & 47 \\
\hline$($ day -4$)$ & & & $\mathrm{EB}^{* * *}: 4$ & & & \\
\hline 37 & 10 & $14^{* *}$ & B : 8 & & 12 & 86 \\
\hline$($ day-4) & & & EXB : 6 & 111 & (5) & \\
\hline
\end{tabular}

ソ（ケタラール, 三共）の筋肉内注射 $(15 \mathrm{mg} / \mathrm{kg}$ 体重) および 4 \%ハロセン（フローセン，タケダ）による吸入 麻酶下で開腹手術を行い，両側子宮角を灌流した。子宮 灌流液には，1\%の非働化ウシ胎児血清 (FCS, GIBCO) を添加したダルベッコのリン酸緩衝夜 (PBS) を用いた。 なお，4頭のドナーについては，3〜 7 週間の間隔をお いて採卵手術を反復した。

肧の培養 : 採取した泼のらち一部は, 約20時間 ( 1 晚) 培養後レシピェントに移植した。培養液には， $12 \mathrm{mg} /$ $\mathrm{ml}$ の漲度にウシ血清アルブミンを添加した Whittingham のマウス肧培㕌液 $(\mathrm{M}-16)$ [8]と，16\% FCS 加 PBSを等量ずつ混合したものを用いた。

肧の移植 : 当研究所で飼育されている8ヶ月齢, 体重 約 $110 \mathrm{~kg}$ の交雑種雌ブタ群（ランドレースメ大ヨークシ ヤ一種 $\mathrm{F}_{1}$, 以下 $\mathrm{LW}$ 種とする) のらち、ミニブタドナ
ーより 1 3 日遅く発情を示したブタ 2 頭を選びレシピ エントに用いた。レシピェントの発情は, 毎日 1 回の試 情によって確認し, 雄許容開始日を day-0 としてday4 亿開腹手術を行い, 形態的に正常と判断されたミニブ 夕肧を子宮角先端付近に少量の培養液と共に移植した。 1 頭のレシピエントには， 5 細胞期 初期肧政胞期の胚 を19個, 他の 1 頭には胚盤胞及び払張期胚盤14個を移植 した。

合計 9 回の肧採取の結果を Table 1 にまとめた。自然 排卵したドナーからは，1 頭当たり 2〜 7 個, 多排卵処 理豚からは 1 頭当たり 7 １5個の肧および未受精卵が得 られた。採取された泼の発達段階を, 採卵日 (day) の等 しいドナー間で比較すると，例えば day- 5 の場合には 2 細胞期から肧盤胞期までのばらつきが認められた。この 原因として，ひとつに自然排卵（\#34）と誘起排卵（\$2， 
6) との差が考えられた。また，本研究で用いたゲッチ ンゲン系ミニブタの発情期間は，2 4 日間と個体差が 著しくこのことから，各ドナー間には排卯日のばらつ きがあり，それが胚の発達段階の差となって現れたもの と推測された。従って今後, ミニブタから希望通りの発 達段階の胚を効率よく採取するためには，ミニブタの性 周期の内分泌動態を明確にし，多排卵処理方法に検討を 加える必要があろう。

ミニブタ胚を， 2 頭の $\mathrm{LW}$ 種レシピエントに移植した 結果を Table 2 に示す。合計19個のミニブタ胚を移植 したレシピェント \#39からは，妊娠112日目に9頭（o： \&=6:3), また14個のミニブタ肧を移植したレシピ エント\#37からは，妊娠111日目に12頭（す： $\$=7 ：$

5 ) の産子が得られた。

レシピエント\#39において, 移植したミニブタ胚の産 子への発生率は47\%であり,この成績は通常のブタ肧移 植における肧の産子への発生率が60\% [1] であるのと 比較して低かった。これは, 移植した $5 \sim 8$ 細胞期のミ ニブタ胚のうちで最も早い発達段階の肧数個が day- 4 のレシピェントに移植する肧の発達段階としては，必ず しも適当ではなかったと考えられる。

合計21頭の産子のらち，12頭は死産であった。出生時 の子ブタ（死産を含む）の体重は, 最も小さかった $270 \mathrm{~g}$ の 1 頭（出生後 5 日目に死亡）を除き， $350 \sim 650 \mathrm{~g}$ で, 通常の分婏に於けるミニブタの生時体重 [6] と差異は なかった。死産の子ブタは, いずれす体重, 外観共に正 常であったことから，出生時に産道内で窒息死したもの と推測された。窒息の原因として，第一にミニブタ胎児 の臍帯長が，レシピエントである家畜ブタの産道との対 比において十分でなく，そのため婏出される胎児の䐤帯 の切断が早期に起きた可能性があること, 第二に, ミニ ブタ胎児が著しく小型であるため, 子宮の収縮による胎 児の婏出が効果的に行われず, 胎児が産道内に長時間停 滞したと思われることがあげられる。今回の実験では， レシピェントとして交雑種（LW 種）の未経産ブタを用 いたが，更に若い雌を使用して母親と産子との体格差を なるべく小さくすること，また介護分婏を行うことで死 産は減少すると考えられる。生存産子は，以後 LW 種 レシピェントによって自然に哺育され，離乳時までの成 長は正常値 (日本 EDM 社 : ゲッチンゲンミニブタ成 長記録より）と変わらなかった。

近年相次いで種々のミニブタの采統が作出され，有名
なものとしては、ミッネタ (Minnesota) 系, ゲッチン ゲン (Göttingen) 系, ユカタン (Yucatan) 系、ネブ ラスカ (Nebraska) 系, ホーメル (Hormel) 系, NIH 系 [2]などがあげられる $[5 ， 6]$ 。これらのミニブタ は，それぞれに特性があり，研究目的に合せて各系統の ブタが使用されることが望ましい。しかし，海外で作 出, 維持されているミニブタを導入することは, 防疫上 の理由などから種々の制的を受ける。更に生体の輸送 と, その後の系統維持には, 多くの経費と労力を要する [5]。そこで希望する系統のミニブタ胚を海外から輸送 し, 国内の家畜ブタのレシピエントに移植することで, 各種ミニブタを容易に国内に導入しらる可能性がある。 また, 清浄に採取, 処理したミニブタ肧を, SPF の家 畜ブタに移植することで, ある系統のミニブタを SPF 化することる可能であると考えられる。

\section{要約}

ゲッチンゲン系ミニブタから初期胚を採取し, 家畜ブ タへ移植してミニブタの生産を行った。胚の採取および 移植は, 外科的手術により行った。雄許容開始後 $2 \sim 6$ 日に胚の採取を行った結果, 1 頭当たり自然排卵では 2 〜 7 個, 誘起排卵では 7 15個の胚および末受精卵が得 られた。33個のミニブタ胚を2 頭の家畜ブタレシピェン トに移植した結果, 21頭の産子が得られたか，12頭は死 産であった。死産の原因は, 分婏時の窒息と考えられ た。本研究で行った胚移植技術を用いたミニブタの生産 は, 特殊なミニブタの系統を海外から導入することや， $\mathrm{SPF}$ ミニブタの作出のために極めて有効な手段と思わ れる。

\section{文 嶰}

[1] Polge, C. (1977). Embryo Transfer. In Farm Animal, pp. 45-47, Betteridge, K. J. (edit.), Canada Department of Agriculture., Canada.

［2] 坂本 櫓・落合武徳 - 磯野可一 (1987). Medical Im munology, 13, 275-280.

[3] 谷岡功邦. (1979). ファルマシァ, 15, 1026-1028.

[4] 谷岡功邦. (1979). 実験動物の飼育管理と手技, ソフト サイエンス社, 85-96.

[5] 谷岡功邦. (1984). 開発途上の実倹動物, 清至書院, 141 -158 .

[6] 谷岡功邦. (1984). 実険医学, 2, 629-633.

[7] 谷岡功邦. (1987). 遣伝, 41, 44-47.

[8] Whittingham, D. G.,(1971). J Reprod Fert Suppl, 14, 7-21. 